\title{
地域間の相互作用に基づく地理的重要度の理論 \\ A THEORY OF GEOGRAPHICAL SIGNIFICANCE BASED ON SPATIAL INTERACTION
}

\author{
鵜 飼 孝盛*，栗田＼cjkstart治** \\ Takamori UKAI and Osamu KURITA
}

\begin{abstract}
In this study, we discuss the distribution of geographical significance, which is caused by accumulated interaction of the activity at point in cities among traffic network. The geographical significance is derived under a recursive structure below; (1) the activity value at one point is calculated by considering the effects from other points of traffic network, (2) that point also affects other points through traffic network according to the activity value of that point.

There is a study which considers such recursive structure of activity, that focuses on the eigenvector corresponding to the maximum eigenvalue of the adjacency matrix of graph. However, it is difficult to interpret the value at each point physically. To dissolve such logical weakness, we provides a logical basis to quantitative index of geographical significance by formulating activity distribution based on maximizing interaction between any two points of traffic network.
\end{abstract}

Keywords : activity distribution, spatial interaction, area reachable within a certain time アクティビティ分布, 空間相互作用, 時間圈域

\section{1. はじめに}

都市は人々が集まり，他者と交わることにより生じる利益を分 け合うことで成り立っている，ある地点にいる人は，その周囲の 人々から影響を受け，また自分自身が周囲に影響を与えている. このような相互作用のやり取りの結果, 都市における様々なアク ティビティ（活動度）の分布が形成されていくここでいうアク ティビティとは, 都市内の人や事業所などの活動の主体のことで あり，これらの主体は日常の生活において他の主体と相互に影響 を及ほしあいながら存在している，一例として商業活動を考えれ ば，ある地点のアクティビティを表す指標としては，その地点に おける店舗の数や店舗面積などが考えられる.これらの店舗は, 競合あるいは協調する他の店舗や客となる人との相互交流の量に 依存して利益を生み出す。この場合，アクティビティ間の相互作 用は商取引の回数や金額の多塞などで測ることができよう．従っ て，相互作用の大きな地点では商取引の機会が増えるため, 多数 の店舗が進出し, 店舗（の集合）の規模が拡大されることになる.

上記のような店舗の出店などを論じる際しばしば問題とされる のが，地の利の良し悪しである，ある土地の地理的重要性あるい は地の利は，その土地の物理的な位置により生じる利便性につい
て述べたものであり, 我々がこれを口にするときには周辺の地域 との関係に基づいてその良し悪しを判断している，すなわち，あ る地点の地の利は, 周辺の地域との交流, 周辺の地域へのアクセ ス，あるいは周辺の地域からのアクセスが容易であるか否かに応 じて認識されているのである．地の利を判断する際に，上述の 2 地点間の移動の容易さとともに，考慮に入れなければならないの がどのような地点から影響を受けるかである．都市内の各地点は それぞれ個別に存在するのではなく，他の地点と相互に影響を及 ほしあっている，そして，ある地点が他の地点から受ける影響の 大きさは, どの地点からのものも等しいというわけではない，人 や事業所といったアクティビティが密集している地点からは大き な影響を受けるだろうし，逆に踈らであるような地点からの影響 はほとんどないだろう．従って，アクティビティが多く存在する ような地点への移動が容易であるか否かによりその地点と他の地 点との間での相互の交流の量が定まり，地の利が定まるのである.

前述のように，都市内の活動の主体であるアクティビティは， その地点の利便性に応じて分布すると考えられる. 他の地点に存 在するアクティビティとの交流が容易であるかどうか, 周辺の地 域にアクセスしやすいか否かによってその位置を決定するのであ
* 慶應義熟大学大学院理工学研究科 特別助手. 博士 (工学) ** 慶㗹義塾大学理工学部管理工学科 教授・学博
Research Assoc., Faculty of Science and Technology, Keio University, Dr. Eng. Prof., Dept. of Administration Engineering, Faculty of Science and Technology, Keio University, Ph. D. 
る. そして，人々が交通路あるいは交通網を通じてある地点から 別のある地点へと移動していく以上，都市内の各地点のアクティ ビティ間で生じる相互交流もまた交通網の形状に依存するのであ る.すなわち，地の利の良い場所にアクティビティは多く存在す ることになるのである.

上記のような，(i)ある地点の地の利は，交通網を介して，他の 地点からそれらの地点の地の利に态じた影響を受け決定し, (ii) そ の地点自身もまた，交通網を介して，地の利に态じた影響を周囲 に与えるという地の利の再帰的構造を定量的に評価するために， 野田 ${ }^{3)}$ は交通網を表現したグラフの隣接行列の最大固有值に属す る固有べクトルを用いている．しかしながら，そこで得られる各 地点の值を具体的な物理量として解釈することは困難であり，こ のような值が得られる理論的な説明はなされていない.

上記の地の利の定量的指標である地利値に理論的根拠を与え， その数理的性質を解明することが本論文の目的である．以下では 想定する都市領域全体の相互作用の総和を最大化するアクティビ ティの分布を求め, 地の利をアクティビティの関数として記述す ることで，地利値が導かれることを示す．またモデルを発展させ ることで, 実は時間圈域の面積 ${ }^{2)}$ といった他の地理的重要度の指 標と地利値との間に興味深い関係性が存在することも示される.

\section{2. 隣接行列の固有ベクトル}

鉄道や道路などの交通網において，交差点や駅などの結節点を 頂点, 鉄道路や道路などの交通路を辺としたグラフ $G$ を考える. 頂点の数を $n$ 個, 辺の本数を $m$ 本とし, グラフ $G$ の頂点の集合を $V(G)=\left\{v_{1}, v_{2}, \ldots, v_{n}\right\}$, 辺の集合を $E(G)=\left\{e_{1}, e_{2}, \ldots e_{m}\right\}$ とする. このグラフ $G$ に対しその隣接行列を $A$ とする.

$$
A=\left(a_{i j}\right), \quad a_{i j}=\left\{\begin{array}{l}
1:\left(v_{i}, v_{j}\right) \in E(G) \\
0:\left(v_{i}, v_{j}\right) \notin E(G)
\end{array}\right.
$$

この隣接行列 $A$ の絶対値最大の固有值に属する固有ベクトルを 考える.すなわち, $\lambda$ を固有值， $\boldsymbol{x}$ をこれに属する固有ベクトル として，以下を満たすような $\boldsymbol{x}$ を考える:

$$
A \boldsymbol{x}=\lambda \boldsymbol{x}
$$

このとき, $\boldsymbol{x}$ の第 $i$ 成分 $x_{i}$ は頂点 $v_{i}$ に対応し,

$$
x_{i}=\frac{1}{\lambda} \sum_{j=1}^{n} a_{i j} x_{j}=\frac{1}{\lambda} \sum_{a_{i j}=1} x_{j}
$$

と表される。ここで， $a_{i j}$ は頂点 $v_{i}$ と $v_{j}$ とが隣接しているとき に 1 ，そうでなければ 0 となるので，頂点 $v_{i}$ における值 $x_{i}$ は頂 点 $v_{i}$ に隣接する頂点における值の総和に比例することになる.

上記の性質は，以下のように言い表すことができる：

『ある地点の魅力度は

i) その地点が他の地点と緊密に隣接する程

ii）隣接する地点の魅力度が大きい程

大きくなる.』

野田 ${ }^{3,4)}$ は, 式 (3) で定義される各地点の值を「各地の地の利（魅 力）を表す定量的指標」として捉え，地利值と呼んでいる. 式 (3) から判るように, 任意の地点 $v_{i}$ の地利值（魅力度） $x_{i}$ は周囲の

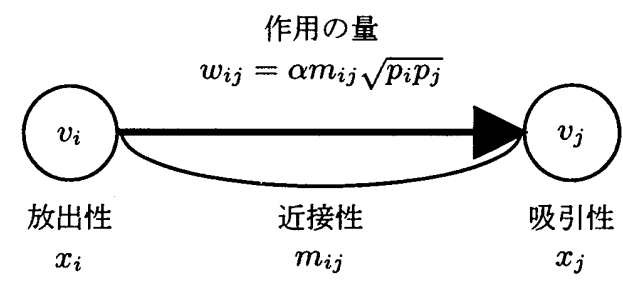

図 12 点 $v_{i}, v_{j}$ 間の相互作用

地点からの影響を受けて決まり, さらにその地点の地利値が周囲 の地点に影響を与えるといった再帰的な構造を有している.

また, 地利值は隣接行列の固有ベクトルであることから, 任意 の地点における地利值の值そのものには絶対的な意味はなく, 他 の地点と比較して, 相対的に地の利が大きいか否かを示している にすぎないことに注意されたい。

\section{3. 都市内の総相互作用の最大化}

この章では, 都市内の各地点における魅力度（ポテンシャル） をアクティビティの関数として与え, 地点間で相互に及ぼしあう 影響の総量を最大化することを考える.このとき，いくつかの仮 定の下に得られる魅力度の分布が, 地利値 ${ }^{3,4)}$ と等しくなること を示す。

都市内に $n$ 個の地点を考え, 任意の地点 $v_{i}$ における, 人口や 事業所などのアクティビティの量を $p_{i}$ とし, $\boldsymbol{p}=\left(p_{1}, \ldots, p_{n}\right)^{T}$ とする. 各地点に分布するアクティビティの都市内での総量は $P$ で一定とする.

$$
P=\sum_{i=1}^{n} p_{i}
$$

地点 $v_{i}$ の魅力度 $x_{i}$ はその地点におけるアクティビティの量 $p_{i}$ に依存するものとする．地点 $v_{i}$ の魅力度（ポテンシャル） $x_{i}$ を アクティビティの量 $p_{i}$ の関数 $f\left(p_{i}\right)$ として与える. 関数 $f$ は以 下の性質を持つものとする.

$$
f>0, \quad f^{\prime}>0, \quad f^{\prime \prime}<0
$$

すなわち， $x_{i}$ は $p_{i}$ について凹であるものとする.このような関 数 $f$ は様々に考えられるが,ここでは地利値その一例としてアク ティビティの正の平方根を導入する.

$$
x_{i}=f\left(p_{i}\right)=\sqrt{p_{i}}
$$

この設定の下では，後述の最大化問題が解析的に解け，式 (3) で 定義される地利値と等しくなる，という著しい特長をもつことに なる. 吻論, $f$ に他の関数形を与えることも可能であるが, その 場合は以下の最大化問題が必ずしも解析的には解けず, 数值的に 取り扱う必要が生じる.

ここで, 2 地点 $v_{i}-v_{j}$ 間の相互作用の量はそれぞれの魅力度 $x_{i}$, $x_{j}$ の積に比例するものとし, 比例定数 $\alpha$ を用いて $\alpha m_{i j} x_{i} x_{j}$ と 表されるものとする. ただし, $m_{i j}$ は 2 地点 $v_{i}-v_{j}$ 間の近接の度 合いに応じて定まる非負の定数であり，地点間の移動の所要時間 や移動距離によって定まるものである．従って，任意の $v_{i}, v_{j}$ に 対して，その近接の度合いは，

$$
m_{i j}=m_{j i} \geq 0
$$


であるものと考えられる（図 1)。このとき，相互作用の都市全体 での総和 $g(\boldsymbol{p})$ は以下のようになる.

$$
\begin{aligned}
g(\boldsymbol{p}) & =\sum_{i=1}^{n} \sum_{j=1}^{n} \alpha m_{i j} x_{i} x_{j} \\
& =\sum_{i=1}^{n} \sum_{j=1}^{n} \alpha m_{i j} \sqrt{p_{i} p_{j}}
\end{aligned}
$$

商業活動を例に取れば，アクティビティ $p_{i}$ は各地点における 店舗の数などに相当し，相互作用は各店舗間での商業活動の活発 さ・商取引の多塞に相当する，その場合，相互作用の総量である $g(\boldsymbol{p})$ は都市全体での商業活動の活発さを示すものとなり，売上の 総量にあたるものと考えられる．以下では，限られた店舗の数の 中で，社会全体で相互交流に基づく売上を最大化するような店舗 の分布を求める.

いま，都市全体でのアクティビティが一定という状況下で，都 市内の相互作用の総和を最大化することを考える.すなわち，式 (4) の制約の下で式 (8) を最大化する問題を考える.

$$
\begin{array}{ll}
\max _{\boldsymbol{p}} & \sum_{i=1}^{n} \sum_{j=1}^{n} \alpha m_{i j} \sqrt{p_{i} p_{j}} \\
\text { s.t. } & \sum_{i=1}^{n} p_{i}=P
\end{array}
$$

上記の最大化問題は次の関数 $L(\boldsymbol{p} ; \mu)$ を最大化することと等しい.

$$
L(\boldsymbol{p}, \mu)=\sum_{i=1}^{n} \sum_{j=1}^{n} \alpha m_{i j}+\mu\left(P-\sum_{i=1}^{n} p_{i}\right)
$$

ただし， $\mu$ はラグランジュ乗数である. 1 階の条件は,

$$
\frac{\partial L(\boldsymbol{p}, \mu)}{\partial p_{k}}=\sum_{j=1}^{n} \alpha m_{k j} \sqrt{\frac{p_{j}}{p_{k}}}-\mu=0
$$

となり，以下を得る。

$$
\sum_{j=1}^{n} m_{i j} \sqrt{p_{j}}=\frac{\mu}{\alpha} \sqrt{p_{i}}=\lambda \sqrt{p_{i}}
$$

ただし， $\lambda=\mu / \alpha$ である. 式 (6) で定めたように, $x_{i}=\sqrt{p_{i}}$ な ので，上式は

$$
\lambda x_{i}=\sum_{j=1}^{n} m_{i j} x_{j}
$$

のように書き表される. $\boldsymbol{x}=\left(x_{1}, \ldots, x_{n}\right)^{T}, M=\left(m_{i j}\right)$ とし て, 式 (12)を行列形式で書き表すと, 以下のようになる.

$$
M x=\lambda \boldsymbol{x}
$$

$m_{i j}$ は 2 地点 $v_{i}-v_{j}$ 間の近接の度合いを表す定数であり，式 (7) のように仮定されている. 従って, 行列 $M$ は全成分が非負の実 対称行列であるので, ペロン・フロベニウスの定理より，『行列 $M$ には絶対值最大となる正の固有值 $\lambda$ が存在し，その最大固有 值には非負の成分からなる固有べクトルが属する』ことがわかる. 従って, 魅力度 $x_{i}$ のベクトル $\boldsymbol{x}$ は, 2 地点 $v_{i}-v_{j}$ の近接度 $m_{i j}$ を要素とする行列 $M$ の固有ベクトルということがわかる.
$L(\boldsymbol{p}, \mu)$ が最大となるときのラグランジュ乗数 $\mu$ は

$$
\mu=\frac{\alpha \sum_{j=1}^{n} m_{i j} \sqrt{p_{j}}}{\sqrt{p_{i}}}
$$

となる.さらに，相互作用の総和 $g(\boldsymbol{p})$ が最大となる $\boldsymbol{p}$ を $\boldsymbol{p}^{*}=$ $\left(p_{1}^{*}, \ldots, p_{n}^{*}\right)^{T}$ とすると，そのときの相互作用の総和 $g\left(\boldsymbol{p}^{*}\right)$ は，

$$
\begin{aligned}
g\left(\boldsymbol{p}^{*}\right) & =\sum_{i=1}^{n} \sum_{j=1}^{n} \alpha m_{i j} \sqrt{p_{i}^{*} p_{j}^{*}} \\
& =\alpha \sum_{i=1}^{n} \sqrt{p_{i}^{*}}\left(\sum_{j=1}^{n} m_{i j} \sqrt{p_{j}^{*}}\right)
\end{aligned}
$$

であり，式 (12)，(4) から

$$
\begin{aligned}
g\left(\boldsymbol{p}^{*}\right) & =\alpha \sum_{i=1}^{n} \sqrt{p_{i}^{*}} \times \lambda \sqrt{p_{i}^{*}} \\
& =\alpha \lambda \sum_{i=1}^{n} p_{i}^{*} \\
& =\alpha \lambda P \\
& =\mu P
\end{aligned}
$$

となる. 式(15)を $\lambda$ について解けば,

$$
\lambda=\frac{g\left(\boldsymbol{p}^{*}\right)}{\alpha P}
$$

となり, 行列 $M$ の最大固有值 $\lambda$ は都市内の相互作用の総量に比 例することがわかる. 地域間の相互作用の量は, 2 地点間の近接 の度合い $m_{i j}$ に依存して定まるものであった. $m_{i j}$ は地点 $v_{i}$ と $v_{j}$ の間の交通路の整備状況などに依存して定まる值である. 交通 路の能力が高ければ，この值は大きくなり，そうでなければ小さ くなると考えられる. 従って, 都市内の相互作用の総量に比例す

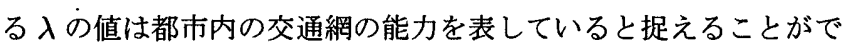
きる. 交通網が存在しないときには，相互作用は発生しないが， 一度交通網が実現すると，それに忘じて相互作用が生じる．換言 すれば，交通網が存在することによる都市全体の活性度を $\lambda$ は表 現しているのである.

さらに式(12)の両辺を $\lambda$ で割り, 式(16)を代入すると,

$$
\begin{aligned}
x_{i} & =\frac{\alpha P}{g(\boldsymbol{p})} \sum_{j=1}^{n} m_{i j} x_{j} \\
& =\alpha P \frac{\sum_{j} m_{i j} x_{j}}{\sum_{j} \sum_{k} \alpha m_{j k} x_{k}} \\
& =P \frac{\sum_{j} m_{i j} x_{j}}{\sum_{j} \sum_{k} m_{j k} x_{k}}
\end{aligned}
$$

となり，次のような解釈が成り立つ. 都市内の魅力度の分布は, 都市内の相互作用の総和に対するその地点における相互作用の量 の割合と都市内の人口の積で表される.

またこれまでのモデルにおける近接の度合い $m_{i j}$ を交通網の 隣接行列の要素 $a_{i j}$ で置き換えることで, 交通網の位相的特性の みに依存したアクティビティの分布を得ることできる. 式 (3) を 見れば明らかなように，このようにして得られるアクティビティ の分布は地利値そのものであることがわかる. 従って, 地利値と は地点間の相互作用が交通網上の隣接した頂点間でのみ生じるよ 
うな状況下で, 都市内の相互作用の総和を最大化するようなアク ティビティの分布を表すものであることがわかる.

更に, $a_{i j}$ が常に一定の值 $a$ をとるような場合, すなわち都市 内の全ての地点間の結びつきが一定であるような場合について考 える. 対称性から明らかに, 任意の $i, j$ について $p_{i}=p_{j}$ であ り, $\sum_{i} p_{i}=P$ から

$$
p_{i}=\frac{P}{n}
$$

である.これと式 (16)から

$$
\begin{aligned}
\lambda & =\frac{\sum_{i} \sum_{j} a \sqrt{\frac{P}{n}} \sqrt{\frac{P}{n}}}{P} \\
& =a n
\end{aligned}
$$

を得る. $a=1$ の場合, これに対応するグラフは完全グラフであ り, その固有值は頂点数 $n$ に等しくなる.

\section{4. 単位アクティビティあたりの相互作用}

前節のように, 相互作用の総和が最大となったときの, 各地点 での単位アクティビティあたりの相互作用の量を求めよう。これ は個々のアクティビティがどの程度交通網の恩恵を享受するかを 示すものであり，そのばらつきは公平性を表すことになる.

いま都市全体での相互作用の総和が最大化されたときの $\boldsymbol{p}$ を $\boldsymbol{p}^{*}$ とし, $\boldsymbol{p}^{*}=\left(p_{1}^{*}, \ldots, p_{n}^{*}\right)^{T}$ とする. 任意の地点 $v_{i}$ における相 互作用の量は,

$$
\sum_{j=1}^{n} \alpha m_{i j} \sqrt{p_{i}^{*} p_{j}^{*}}
$$

で表される. 地点 $i$ のアクティビティの量は $p_{i}^{*}$ なので, 地点 $v_{i}$ におけるアクティビティ 1 単位あたりの相互作用の量 $r_{i}^{*}$ は,

$$
r_{i}^{*}=\frac{\sum_{j} \alpha m_{i j} \sqrt{p_{i}^{*} p_{j}^{*}}}{p_{i}^{*}}=\frac{\alpha \sum_{j} m_{i j} \sqrt{p_{j}^{*}}}{\sqrt{p_{i}^{*}}}
$$

となる.ここで, 式(11) から, $\sum_{j} m_{i j} \sqrt{p_{j}^{*}}=\lambda \sqrt{p_{i}^{*}}$ なので,

$$
r_{i}^{*}=\frac{\alpha \lambda \sqrt{p_{i}^{*}}}{\sqrt{p_{i}^{*}}}=\lambda \alpha=\mu
$$

となり, 都市全体での相互作用の総和が最大となるとき, 各地点 における単位アクティビティあたりの相互作用は, 地点によらず 一定であり，その值はラグランジュ乗数 $\mu$ となる.

$\boldsymbol{p}^{*}$ は都市全体での相互作用の総和を最大化するようなアク ティビティの分布であり, 個々のアクティビティが受ける相互作 用については何ら考虑していない。このような状況であるにも関 わらず，個々のアクティビティが交通網から享受する相互作用は 一定であり，公平性が確保されるということが示された。

\section{5. 個別に相互作用を最大化することによる均衡}

ここまでは, 都市全体での相互作用が最大となるようなアク ティビティの分布 $\boldsymbol{p}$ を求めてきた. この節では, アクティビティ がそれぞれ個別に相互作用を最大化するような状況を考える.ア クティビティ同士の相互交流に比例して商業活動などを行うと考 えると，それぞれのアクティビティは出来るだけ有利な地点，す なわち相互作用を大きくすることができる都市内の別の地点へと
移ることになる．ここでは，都市内の相互作用の総和が最大化さ れたようなアクティビティの分布が，アクティビティが主体的に 相互作用を大きくすることを試みたときに，別の地点へ移動する ことにより，相互作用を大きくすることができないという均衡状 態となることを示す.

都市全体での相互作用の総和が最大化されたときの $\boldsymbol{p}$ を $\boldsymbol{p}^{*}$ と し, $\boldsymbol{p}^{*}=\left(p_{1}^{*}, \ldots, p_{n}^{*}\right)^{T}$ とする. いま，地点 $v_{k}$ におけるアクティ ビティ $p_{k}^{*}$ のうち, $\Delta p$ が $v_{k}$ 以外の地点 $v_{l}$ 一移動することを考え る. ただし， $\Delta p$ は十分に小さな単位であるものとし，その移動 する先は高々 1 つであるものとする.この $\Delta p$ の移動が生じるた めには，移動する前に比べて移動することが有利である，すなわ ち移動後の地点 $v_{l}$ における単位アクティビティあたりの相互作 用が，移動前の地点 $v_{k}$ におけるそれよりも大きくなる必要があ る.ここでは，移動後の単位あたりの相互作用が移動前のそれに 比べて小さくなることを示すことにより，都市内の相互作用の総 和が最大化された状態からアクティビティの移動が生じないこと を導く

$\Delta p$ 移動した後のそれぞれの地点におけるアクティビティは,

$$
\left\{\begin{array}{l}
p_{i}=p_{i}^{*} \quad(i \neq k, l) \\
p_{k}=p_{k}^{*}-\Delta p \\
p_{l}=p_{l}^{*}+\Delta p
\end{array}\right.
$$

となる. $\Delta p$ 移動後の地点 $v_{l}$ における相互作用の和は,

$$
\begin{aligned}
& \sum_{j} \alpha a_{l j} \sqrt{p_{l} p_{j}} \\
= & \alpha \sum_{j=1}^{n} a_{l j} \sqrt{p_{l} p_{j}^{*}}+\alpha a_{l k} \sqrt{p_{l}}\left(\sqrt{p_{k}}-\sqrt{p_{k}^{*}}\right) \\
& +\alpha a_{l l} \sqrt{p_{l}}\left(\sqrt{p_{l}}-\sqrt{p_{l}^{*}}\right)
\end{aligned}
$$

となる. 単位あたりの相互作用は, 上式を $p_{l}$ で除して

$$
\begin{aligned}
r_{l} & =\frac{\alpha \sum_{j} a_{l j} \sqrt{p_{l} p_{j}}}{p_{l}} \\
& =\frac{\alpha}{\sqrt{p_{l}}}\left\{\sum_{j=1}^{n} a_{l j} \sqrt{p_{j}^{*}}+a_{l k}\left(\sqrt{p_{k}}-\sqrt{p_{k}^{*}}\right)+a_{l l}\left(\sqrt{p_{l}}-\sqrt{p_{l}^{*}}\right)\right\}
\end{aligned}
$$

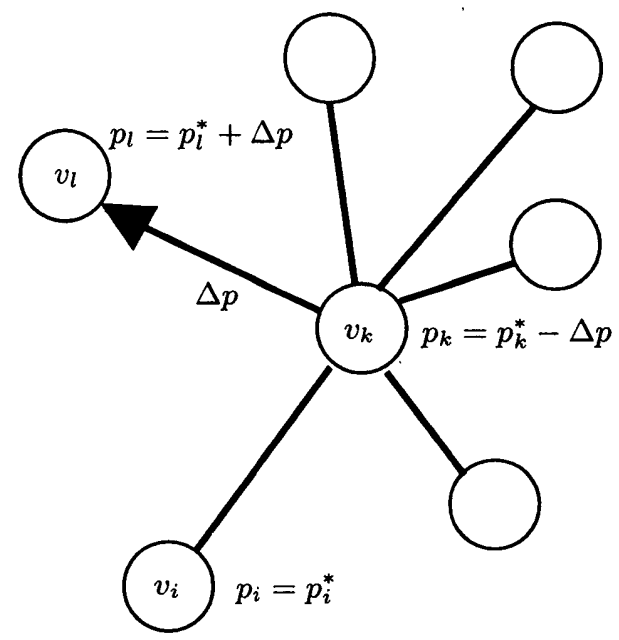

図 $2 \Delta p$ だけのアクティビティの移動 
となる. 式(11)より, $\sum_{j} a_{l j} \sqrt{p_{j}^{*}}=\lambda \sqrt{p_{l}^{*}}$ なので,

$$
r_{l}=\frac{\alpha \lambda \sqrt{p_{l}^{*}}}{\sqrt{p_{l}}}+\frac{\alpha a_{l k}\left(\sqrt{p_{k}}-\sqrt{p_{k}^{*}}\right)+\alpha a_{l l}\left(\sqrt{p_{l}}-\sqrt{p_{l}^{*}}\right)}{\sqrt{p_{l}}}
$$

となる. 移動前の地点 $v_{k}$ における単位アクティビティあたりの 相互作用 $r_{k}^{*}$ は，式(21)より $k$ によらず $\mu=\alpha \lambda$ で一定なの，で，

$$
\begin{aligned}
& r_{k}^{*}-r_{l} \\
= & \frac{\alpha \lambda \sqrt{p_{l}}-\alpha \lambda \sqrt{p_{l}^{*}}}{\sqrt{p_{l}}} \\
& -\frac{\alpha a_{l k}\left(\sqrt{p_{k}}-\sqrt{p_{k}^{*}}\right)+\alpha a_{l l}\left(\sqrt{p_{l}}-\sqrt{p_{l}^{*}}\right)}{\sqrt{p_{l}}} \\
= & \frac{\alpha\left(\lambda-a_{l l}\right)\left(\sqrt{p_{l}}-\sqrt{p_{l}^{*}}\right)}{\sqrt{p_{l}}}+\frac{\alpha a_{k l}\left(\sqrt{p_{k}^{*}}-\sqrt{p_{k}}\right)}{\sqrt{p_{l}}}
\end{aligned}
$$

を得る.ここで, 式(23)より $\sqrt{p_{k}^{*}}>\sqrt{p_{k}}$ なので, 右辺第 2 項 は常に正となる. 同様に, $\sqrt{p_{l}}>\sqrt{p_{l}^{*}}$ より, 右边第 1 項の因数 $\sqrt{p_{l}}-\sqrt{p_{l}^{*}}$ はやはり正となる. ここで, 式(12)より,

$$
\sum_{j=1}^{n} a_{l j} \sqrt{p_{j}^{*}}=\lambda \sqrt{p_{l}^{*}}
$$

である. 上式の両辺を $\lambda$ につて解くと,

$$
\begin{aligned}
\lambda & =\frac{1}{\sqrt{p_{l}^{*}}} \sum_{j=1}^{n} a_{j l} \sqrt{p_{j}^{*}} \\
& =\frac{1}{\sqrt{p_{l}^{*}}}\left(a_{l l} \sqrt{p_{l}^{*}}+\sum_{j \neq l} a_{j l} \sqrt{p_{j}^{*}}\right) \\
& =a_{l l}+\frac{\sum_{j \neq l} a_{j l} \sqrt{p_{j}^{*}}}{\sqrt{p_{l}^{*}}}
\end{aligned}
$$

となる. 右辺第 2 項は常に正であるから， $\lambda>a_{l l}$ が成り立ち, 式(27)の右辺第 1 項も正となることがわかる. 従って,

$$
r_{k}^{*}-r_{l}>0
$$

となり，地点 $v_{k}$ から $v_{l}$ へのアクティビティの移動は発生せず， アクティビティの分布 $\boldsymbol{p}^{*}$ は均衡となる.

前章で求めたアクティビティの分布 $\boldsymbol{p}^{*}$ は，アクティビティの 総量が一定という条件下で相互交流の量 $g(\boldsymbol{p})$ を最大化するもの であり，ある種の全体的最適化の解として求まるものであった. 本章では, このようなアクティビティの分布が, 同時にアクティ ビティが個々に自らの相互作用の量を最大化するよう動いた際の 均衡であることを示した. すなわち，政府などの規制に頼ること なく，各アクティビティの自由競争により，都市全体での相互作 用の総和の最大化が達成されるという好ましい状況が示された.

\section{6. 地利値の拡張}

\section{1 隣接行列を拡張した地利值}

式 (3) で定義される地利値は，頂点 $v_{i}$ の地利值 $x_{i}$ はこれに隣 接する頂点 $v_{j}$ の地利值の和に比例するという性質を持っている. 従って，頂点 $v_{i}$ が多くの頂点に隣接する程，值の大きな頂点に隣 接する程，頂点 $v_{i}$ の地利值は大きくなる．しかし，ここでは頂 点 $v_{i}$ に影響を与える頂点 $v_{j}$ の隣接関係については何も注意が払

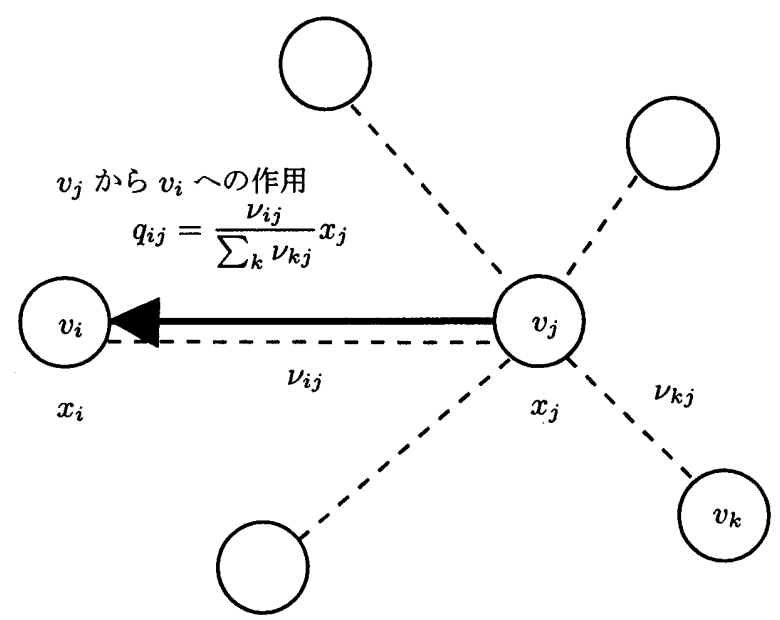

图 3 点 $v_{j}$ から点 $v_{i}$ へはたらく作用

われていない，具体的には，頂点 $v_{j}$ に接続する辺の本数（頂点 $v_{j}$ の次数）が多くても，少なくても頂点 $v_{j}$ が頂点 $v_{i}$ に与える影 響には変化がないのである. ある頂点に隣接する頂点の数が增加 し，その影響の及ぶ範囲が広くなるならば，隣接する一つ一つの 頂点への影響仙小さくなるものと考えられる場合は少なくない，

この節ではこのような地利値が有限な值であるという観点か ら，隣接行列を以下のように定義しなおす. 頂点 $v_{i}$ と $v_{j}$ との間 に何らかの形で記述される効用 $\nu_{i j}$ を考える. ただし， $\nu$ は対称 的であるとし， $\nu_{i j}=\nu_{j i}$ とする. さらに頂点 $v_{i}$ に隣接する全て の頂点への効用の和を $\sigma_{i}$ とする. そして, 頂点 $v_{j}$ から頂点 $v_{i}$ へ の影響は, 頂点 $v_{j}$ から他の頂点の全効用に対する, 頂点 $v_{i}$ への 効用の比と考え，

$$
q_{i j}=\frac{\nu_{i j}}{\sigma_{j}}=\frac{\nu_{i j}}{\sum_{k=1}^{n} \nu_{j k}}
$$

と定める.このような $q_{i j}$ を要素とする行列 $Q=\left(q_{i j}\right)$ を隣接行 列 $A$ の代わりに用いて, その固有値・固有ベクトルを求める（図 3 を参照).

$$
\begin{gathered}
Q x=\rho x \\
\sigma_{i}=\sum_{j=1}^{n} \nu_{i j}
\end{gathered}
$$

行列 $Q$ の定義からも明らかなように, 行列 $Q$ の列和は常に 1 となる. 事実, 効用が $\nu_{i j}=\nu_{j i}$ であるため，

$$
\sum_{i=1}^{n} q_{i j}=\sum_{i=1}^{n} \frac{\nu_{i j}}{\sum_{k=1}^{n} \nu_{j k}}=\frac{\sum_{i=1}^{n} \nu_{i j}}{\sum_{k=1}^{n} \nu_{j k}}=1
$$

となる.

このような行列の固有值は 1 となることが知られている. 式 (31) を第 $i$ 行について書き下すと,

$$
\rho x_{i}=\sum_{j=1}^{n} q_{i j} x_{j}
$$

であり，これを両辺を $i$ にいて加え合わせると，左辺は

$$
\sum_{i=1}^{n} \rho x_{i}=\rho \sum_{i=1}^{n} x_{i}
$$


であり, 右辺は

$$
\sum_{i=1}^{n} \sum_{j=1}^{n} q_{i j} x_{j}=\sum_{j=1}^{n} x_{j}\left(\sum_{i=1}^{n} q_{i j}\right)=\sum_{j=1}^{n} x_{j}
$$

となることから， $\rho=1$ であることがわかる

$$
\text { よって, }
$$

$$
Q \boldsymbol{x}=\boldsymbol{x}, \quad x_{i}=\sum_{j=1}^{n} q_{i j} x_{j}
$$

が成り立つ. 式(30)より, $\nu_{i j}=\sigma_{i} \cdot q_{j i}=\sigma_{j} \cdot q_{i j}$ であるから, $q_{i j}=\frac{\sigma_{i}}{\sigma_{j}} q_{j i}$ なので,

$$
x_{i}=\sum_{j=1}^{n} q_{j i} \cdot \frac{\sigma_{i}}{\sigma_{j}} \cdot x_{j}
$$

となる. 両辺を $\sigma_{i}$ で割り $\frac{x_{k}}{\sigma_{k}}=\psi_{k}$ とおくと，

$$
\psi_{i}=\sum_{j=1}^{n} q_{j i} \psi_{j}
$$

となる.さらに, $q_{j i}=\frac{\nu_{i j}}{\sigma_{i}}$ を代入し, 両辺に $\sigma_{i}$ を乗じると左 辺は,

$$
\psi_{i} \sigma_{i}=\psi_{i} \sum_{j=1}^{n} \nu_{i j}=\sum_{j=1}^{n} \psi_{i} \nu_{i j}
$$

であり，右辺は

$$
\sum_{j=1}^{n} \frac{\nu_{j i}}{\sigma_{i}} \psi_{j} \sigma_{i}=\sum_{j=1}^{n} \psi_{j} \nu_{j i}
$$

となり, $\nu_{i j}=\nu_{j i}$ であるから，

$$
\psi_{i}=\psi_{j}, \quad \frac{x_{i}}{\sigma_{i}}=\frac{x_{j}}{\sigma_{j}}
$$

が得られる. 従って,

$$
x_{i}: x_{j}=\sigma_{i}: \sigma_{j}=\sum_{j} \nu_{i j}: \sum_{i} \nu_{i j}
$$

であり, 都市内の任意の地点 $v_{i}$ における值は, 地点 $v_{i}$ から全て の他の地点への効用の和に比例することになる.

さらに, 地点 $v_{i}$ と $v_{j}$ 間の効用 $\nu_{i j}$ を隣接行列の要素とした場 合, すなわち $\nu_{i j}=a_{i j}$ とした場合, $\sigma_{i}=\sum_{j} a_{i j}, q_{i j}=\frac{a_{i j}}{\sigma_{j}}$ と なるので,

$$
x_{i}: x_{j}=\sum_{j} a_{i j}: \sum_{i} a_{i j}=d\left(v_{i}\right): d\left(v_{j}\right)
$$

となる. ただし， $d\left(v_{i}\right)$ は頂点 $v_{i}$ に接続する辺の本数であり，各 頂点における地利値はそれぞれに接続する辺の本数, すなわち隣 接する頂点の数に比例することとなる．このとき，頂点 $v_{j}$ が隣 接する全ての頂点へ与える影響に対する, 頂点 $v_{i}$ への影響の割 合は,

$$
q_{i j}=\frac{a_{i j}}{\sigma_{j}}=\frac{a_{i j}}{d\left(v_{j}\right)}
$$

であり, 頂点 $v_{j}$ の次数に反比例する. 頂点 $v_{j}$ から $v_{i}$ への影響 は，これに頂点 $v_{j}$ の地利値 $x_{j}$ を乗じたものとなる. 地利值 $x_{j}$
は頂点 $v_{j}$ の次数 $d\left(v_{j}\right)$ に比例する. 比例定数 $k$ を用いて，

$$
x_{j}=k d\left(v_{j}\right)
$$

と表すと，頂点 $v_{j}$ から $v_{i}$ への影響は

$$
q_{i j} x_{j}=\frac{a_{i j}}{d\left(v_{j}\right)} \times k d\left(v_{j}\right)=k a_{i j}
$$

となり, 2 つの頂点が隣接していなければ 0 , 隣接しているなら ば一定の值を示す.

また, $a_{i j}$ を 2 点 $v_{i}, v_{j}$ 間の所要時間 $t_{i j}$ がある閥値 $T$ 以下の ときに 1 ，そうでない場合には 0 とした場合， $\sigma_{i}=\sum_{j} a_{i j}$ は頂 点 $i$ から所要時間 $T$ 以内で移動可能な頂点の数を表すこととな り，頂点が平面上に一様に分布しているとすると， $\sigma_{i}$ は時間圈域 の面積を表す. その際, $v_{j}$ から $v_{i}$ への影響 $q_{i j} x_{j}$ は $t_{i j}$ が $T$ 以 下であれば一定の值をとる.

時間圈域の面積 ${ }^{2)}$ は，都市内の任意の地点を起点とし，そこ からある所要時間以内で到達可能な領域の面積を表すものであっ た. 同時に，ある地点 $i$ にい人が，そこから所要時間 $T$ 以内で 到達可能な領域に一様に移動するといった状況で，人口の分布が 一種の平衡状態に達した際の, 各地点における人数の比を表すこ とになる.

\section{2 相互作用の最大化に基づく計算}

3 章では, 都市内の各地点における魅力度をアクティビティの 関数とし，地点間の相互作用の総量を最大化することで，式 (3) で表される地利值 ${ }^{3)}$ が得られるという構造を示した。この節で は, 前節の式 (31) で定義される, 拡張された地利值も, 同様に相 互作用の総和の最大化に基づくものであることを示す．以下の議 論における基本的な流れは 3 章と同一であり，相互作用の定義が 異なる.

都市内の $n$ 個の地点におけるアクティビティの量 $p_{i}$ の都市内 の総量は $P$ で一定であるものとする.

$$
P=\sum_{i=1}^{n} p_{i}
$$

地点 $v_{i}$ の魅力度 $x_{i}$ をアクティビティの量 $p_{i}$ の関数 $f\left(p_{i}\right)$ とし て与える. 以下では, このような関数 $f$ として， 2 章と同様にア クティビティの正の平方根を仮定する.

$$
x_{i}=f\left(p_{i}\right)=\sqrt{p_{i}}
$$

次に 2 地点 $v_{i}-v_{j}$ 間ではたらく作用について考える. 3 章での 相互作用は， 2 地点間の魅力度の積に比例するものとしていた。 ここでは, 地点 $v_{i}$ への地点 $v_{j}$ からの影響が, 地点 $v_{j}$ の魅力度と 2 地点間の近接の度合いのみによって決まるものとし，相互作用 を次式で与える.

$$
w_{i j}=\alpha a_{i j} x_{j}
$$

ただし， $a_{i j}$ は隣接行列の要素であり，交通網により隣接した地点 間でのみ相互作用が生じるといった状況を想定する．このとき， 式(45) から， $x_{j}=\sqrt{p_{j}}$ であるので,

$$
w_{i j}=\alpha a_{i j} \sqrt{p_{j}}
$$


を得る.このとき，相互作用の都市全体での総和は次式となる.

$$
\begin{aligned}
& g(\boldsymbol{x})=\sum_{i=1}^{n} \sum_{j=1}^{n} w_{i j}=\sum_{i=1}^{n} \sum_{j=1}^{n} \alpha a_{i j} x_{j} \\
& g(\boldsymbol{p})=\sum_{i=1}^{n} \sum_{j=1}^{n} \alpha a_{i j} \sqrt{p_{j}}
\end{aligned}
$$

いま，都市全体でのアクティビティが一定という状況下で，都 市内の相互作用の総和を最大化するようなアクティビティの分布 を求めることを考える．すなわち，式 (44) の制約の下で式 (48) を最大化する問題を考える.

$$
\begin{aligned}
\max _{\boldsymbol{p}} & \sum_{i=1}^{n} \sum_{j=1}^{n} \alpha a_{i j} \sqrt{p_{j}} \\
\text { s.t. } & \sum_{i=1}^{n} p_{i}=P
\end{aligned}
$$

上記の最大化問題を解くために, ラグランジュ関数

$$
L(\boldsymbol{p}, \mu)=\sum_{i=1}^{n} \sum_{j=1}^{n} \alpha a_{i j} \sqrt{p_{j}}-\mu\left(\sum_{i=1}^{n} p_{i}-P\right)
$$

を考える．上式を $p_{k}$ で偏微分すると，

$$
\frac{\partial L(\boldsymbol{p}, \mu)}{\partial p_{k}}=\sum_{j=1}^{n} \alpha a_{k j} \frac{1}{2 \sqrt{p_{k}}}-\mu
$$

となる. 従って，1階の条件より以下を得る.

$$
\sum_{j=1}^{n} a_{i j}=\lambda \sqrt{p_{i}}
$$

ここで $\lambda=\frac{2 \mu}{\alpha}$ である. $\sum_{j=1}^{n} a_{i j}=d\left(v_{i}\right), \sqrt{p_{i}}=x_{i}$ であるこ とに注意すると, $\lambda$ は式(43)における比例定数 $k$ の逆数に等しい ことがわかる.

また，都市内の作用の総和が最大となるアクティビティの分布 を $\boldsymbol{p}^{*}=\left(p_{1}^{*}, p_{2}^{*}, \ldots, p_{n}^{*}\right)^{t}$ とすると, 都市内の相互作用の総和は,

$$
\begin{aligned}
g\left(\boldsymbol{p}^{*}\right) & =\sum_{i=1}^{n} \sum_{j=1}^{n} \alpha a_{i j} \sqrt{p_{j}^{*}} \\
& =\alpha \sum_{j=1}^{n} \sqrt{p_{j}^{*}} \sum_{i=1}^{n} a_{i j}
\end{aligned}
$$

であり, 式(51)より $\sum_{i} a_{i j}=\lambda \sqrt{p_{j}^{*}}$ なので,

$$
g\left(\boldsymbol{p}^{*}\right)=\alpha \lambda \sum_{j=1}^{n} p_{j}^{*}=\alpha \lambda P
$$

となる. 式 (3) で定義される地利値の計算における固有值 $\lambda$ と同 様に，抬張された地利值においても， $\lambda$ は都市内の相互作用の総 量に比例することとなり，都市内の交通網の能力や地点間の結び つきの強さを示すことがわかる.

\section{7. まとめ}

本研究では，地利值をアクティビティの関数として新たに定義 しなおし，アクティビティの総量が一定であるという制的の下 で，相互作用の都市内での総和を最大化するようなアクティビ ティの分布を求めることが，上記の地利值を求めることと等価で あることを示した．同時に，上で用いた仮定が成り立つ限り，各
アクティビティが行動の主体として，各地点での相互作用の蓄積 の取り分を個別に最大化するよう行動した際に得られるアクティ ビティの均衡状態と, 上記の都市内の相互作用の総和を最大化す るアクティビティの分布が等しくなることを示した.すなわち， 個々のアクティビティが利己的に，相互作用を最大化することに より，社会全体の相互作用の最大化が達成されることが示された.

また，各地点における地利值が有限であるといら前提から，隣 接行列に変更を加えた. ある地点が他の地点に与える影響は, 隣 接する地点, すなわち影響を及ぼす地点の数に反比例するような 新たな行列を定義し，その固有べクトルという形で地利值の定義 を抁張した.このとき, 適当な式変形を経ることで, 任意の地点 の地利值がその地点の次数, あるいは隣接する地点の数に比例す ることを示した．さらに，隣接行列に適当な仮定をおくことで， 地利值が時間圈域の面積 ${ }^{2)}$ に比例することを示した. 加えて, ア クティビティ間の相互作用の式を変えることで，通常の隣接行列 の固有べクトルとしての地利值の場合と同様に, この㹡張された 地利值が相互作用の総和の最大化に対応することを示した。

このことは, 地利値が時間圈域の概念を更に一般化したもので あることを示しており, 地理的重要性の尺度としての地利値の有 用性を強調することになろう。

本論文に拄ける議論は, 地利值がアクティビティの平方根とし て表わされることを前提としているが，両者の間に他の関数形を 与えた際の性質を探ることは今後の課題として残されている.

\section{謝辞}

本研究は，文部科学省 21 世紀 $\mathrm{COE}$ プログラム『知能化から生 命化へのシステムデザイン』, ならびに科学研究費補助金・基盤 研究 (A)『都市内・都市間交通網と公共施設配置に関する数理的 ならびに実証的研究』(課題番号 17201037)の補助を受けました. ここに記し謝意を表します。

また, 論文内の記述の暧昧さを指摘し, 趣旨がより明膫に伝わ るようコメントを下さった匿名の查読者に感謝いたします。

\section{参考文献}

1) Gould, P.R. : On the geographical interpretation of eigenvalues, Transaction, Institute British Geographers, No.42, pp.53-92, 1967.

2) 腰塚武志: 時間圈域の面積について, 日本オペレーション ズ・リサーチ学会秋季研究発表会アブストラクト集, 2-D-3, pp.176-177, 1985.

3）野田 洋: 街路網の形態的特性に基づく定量的地利値の導入 とその基礎的考察，日本建築学会計画系論文集，第 470 号, pp.139-148, 1995 年 4 月.

4) 野田 洋: 定量的地利尺度を用いた都市街路網の分析的研究, 日本建築学会計画系論文集, 第 519 号, pp.171-178, 1999 年 5 月.

5）瓶饲孝盛・栗田 治: 交通網により生成される都市平面上の 地利值分布一首都圈鉄道網に基づく地利値メッシュ地図一, 都市計画論文集, No. 38-3, pp.163-168, 2003.

6) Tinkler, K.J. : The physical interpretation of eigenfunctions of dichotomous matrices, Transaction, Institute of British Geographers, No.55, pp.17-46, 1972.

7）瓶飼孝盛 : 交通網のグラフ構造と地点間相互作用に基づく都 市内アクティビティ分布の理論, 慶應義塾大学博士学位論文, 2006.

8）山中知彦・原 広司・藤井 明・渡辺健一・小駒幸江: グラフ化 による土地利用図の分析, 都市計画 別冊, No. 16, pp.13-18, 1981. 